\title{
Costunolide-A Bioactive Sesquiterpene Lactone with Diverse Therapeutic Potential
}

\author{
Dae Yong $\mathrm{Kim}^{1}$ and Bu Young Choi ${ }^{2, *(D)}$ \\ 1 Department of Biology Education, Seowon University, Cheongju, Chungbuk 361-742, Korea; \\ kensei@hanmail.net \\ 2 Department of Pharmaceutical Science \& Engineering, Seowon University, Cheongju, \\ Chungbuk 361-742, Korea \\ * Correspondance: bychoi@seowon.ac.kr; Tel.: +82-043-299-8411
}

Received: 23 April 2019; Accepted: 12 June 2019; Published: 14 June 2019

\begin{abstract}
Sesquiterpene lactones constitute a major class of bioactive natural products. One of the naturally occurring sesquiterpene lactones is costunolide, which has been extensively investigated for a wide range of biological activities. Multiple lines of preclinical studies have reported that the compound possesses antioxidative, anti-inflammatory, antiallergic, bone remodeling, neuroprotective, hair growth promoting, anticancer, and antidiabetic properties. Many of these bioactivities are supported by mechanistic details, such as the modulation of various intracellular signaling pathways involved in precipitating tissue inflammation, tumor growth and progression, bone loss, and neurodegeneration. The key molecular targets of costunolide include, but are not limited to, intracellular kinases, such as mitogen-activated protein kinases, Akt kinase, telomerase, cyclins and cyclin-dependent kinases, and redox-regulated transcription factors, such as nuclear factor-kappaB, signal transducer and activator of transcription, activator protein-1. The compound also diminished the production and/expression of proinflammatory mediators, such as cyclooxygenase-2, inducible nitric oxide synthase, nitric oxide, prostaglandins, and cytokines. This review provides an overview of the therapeutic potential of costunolide in the management of various diseases and their underlying mechanisms.
\end{abstract}

Keywords: costunolide; antioxidants; anti-inflammatory; anti-allergic; bone regenerating; neuroprotective; antimicrobial; hair growth promoting; anticancer; antidiabetic properties

\section{Introduction}

Drug development from natural sources, particularly from plants, has long been the mainstay in medical management of various human ailments. A wide variety of non-nutritive plant constituents, commonly known as phytochemicals, are being used as therapy for many disease processes, including, but not limited to, infections, diabetes, heart diseases, neurological disorders, and cancer. In fact, it is estimated that about $40 \%$ of all medicines are natural compounds or their semisynthetic derivatives [1]. One of the major classes of bioactive phytochemicals is the terpenoids, which are widely present in various plants and marine organisms, and are being examined for developing new antifungal, anticancer, anti-inflammatory, and antiviral agents [2]. For example, artemisinin and paclitaxel are terpenoids used clinically as antimalarial and anticancer agents, respectively. The largest group of sesquiterpene lactones is germacranolides [3], which possesses a 10,5-ring structure and is present in several plant families. Germacranolides are key precursors of other sesquiterpene lactones with various polycyclic skeletons, such as guaianolides, eudesmanolides, etc. [4]. Costunolide, a colorless crystalline powder with a molecular formula of $\mathrm{C}_{15} \mathrm{H}_{20} \mathrm{O}_{2}$ and a molecular weight of $232.318 \mathrm{~g} / \mathrm{mol}$, is a well-known sesquiterpene lactone in the germacranolides series. This compound was first isolated 
from costus (Saussurea lappa Clarke) root and then isolated from various other plant species. [5]. Structurally, costunolide (Figure 1) is a monocarboxylic acid having three double bonds which by catalytic hydrogenation generates hexahydrocostunolide. Partial hydrogenation of costunolide produces dihydrocostunolide [6]. The bioactivity of costunolide is mediated through its functional moiety, $\alpha$-methylene- $\gamma$-lactone, which can react with the cysteine sulfhydryl group of various proteins, thereby altering intracellular redox balance [5]. This review is aimed at summarizing the recent research on costunolide, focusing on its therapeutic potential, underlying mechanisms of action, and the prospect of using costunolide for future drug development.

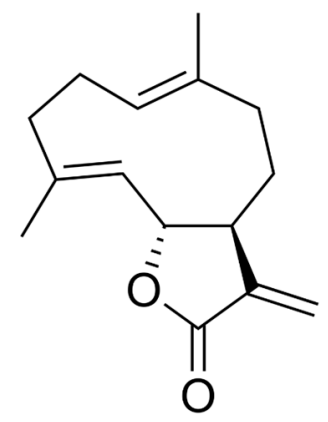

Figure 1. Chemical structure of costunolide.

\section{Therapeutic Potential of Costunolide}

\subsection{Antioxidant and Anti-Inflammatory Effects of Costunolide}

Oxidative stress resulting from cellular redox imbalance leads to many diseases, such as diabetes, atherosclerosis, and cardiovascular diseases [7]. The antioxidant activity of costunolide was studied in streptozotocin (STZ)-induced diabetic rat model, which demonstrated marked reduction in the levels of glutathione (GSH) in the brain, heart, liver, pancreas, and kidney. Oral administration of costunolide restored the GSH level in these tissues [8]. Increased levels of GSH may increase the levels of GSH-dependent enzymes, such as glutathione peroxidase (GPx) and glutathione-S-transferase (GST), thereby reducing tissue damage [9]. Oxidative stress oxidizes and damages membrane phospholipid to produce lipid peroxides, such as malondialdehyde (MDA) and hydroxynonenals (HNE), which by forming DNA adducts may cause oxidative tissue damage. Costunolide also decreased lipid peroxidation levels and increased in SOD, catalase, and GPx activity in MCF-7 \& MDA-MB-231 cells [10]. In a rat intestinal mucositis (IM) model, administration of costunolide restored 5-floirouracil (5FU)-depleted plasma superoxide dismutase (SOD) levels in rat intestinal mucosa [11]. Costunolide also abrogated hydrogen peroxide $\left(\mathrm{H}_{2} \mathrm{O}_{2}\right)$-induced ROS production in rat pheochromocytoma (PC12) cells [12].

Persistent tissue inflammation plays an important role in the pathogenesis of various infectious and noninfectious diseases, such as rheumatoid arthritis, Alzheimer's disease, and arteriosclerosis [13]. Costunolide exhibited anti-inflammatory properties in a number of preclinical studies. The compound attenuated carrageenan-induced paw edema, myeloperoxidase (MPO) activity and $\mathrm{N}$-acetylglucosaminidase (NAG) activity in mice [13]. One of the transcriptional regulators of proinflammatory gene expression is the transcription factor nuclear factor-kappaB (NF- $\mathrm{kB}$ ). Costunolide negated NF- $\kappa B$ activation via blockade of $\mathrm{I} \kappa \mathrm{B} \alpha$ phosphorylation in lipopolysaccharide (LPS)-stimulated RAW264.7 cells, thereby reducing the expression of proinflammatory markers, such as inducible nitric oxide synthase (iNOS), and the production of nitric oxide (NO) [14]. Chen et al. also demonstrated that treatment with costunolide inhibited 5-fluorouracil (5-FU)-induced expression of iNOS, cyclooxygenase-2 (COX-2), TNF- $\alpha$, and the production of nitric oxide (NO) in a mouse model of intestinal mucositis by blocking the activation of NF- $\mathrm{KB}$ [11]. Costunolide diminished STAT1 and STAT3 phosphorylation in IL-22 or IFN- $\gamma$-induced human keratinocytes [15]. Likewise, treatment of human THP-1 cells with costunolide inhibited interleukin (IL)-6-induced phosphorylation and the 
DNA binding activity of signal transducer and activator of transcription (STAT)-3 via downregulation of Janus-activated kinase (JAK)-1 and -2 [16]. Moreover, costunolide showed an anti-inflammatory effect as evidenced by amelioration of ethanol-induced gastric ulcers in mice. This study also reported that the compound suppressed the activation and/or induction of NF-kB, TNF- $\alpha, N O$, iNOS, and COX-2 [17]. Costunolide inhibited interleukin (IL)-1 $\beta$ protein and mRNA expression in LPS-stimulated RAW264.7 cells by blocking activator protein (AP-1) transcriptional activity via downregulation of mitogen-activated protein kinase (MAPK) phosphorylation [18]. In addition, costunolide alleviated lung inflammation in carrageenan-induced mouse pleurisy model as evidenced by reduced accumulation of polymorphonuclear cells and reduced expression of TNF- $\alpha$, intracellular adhesion molecule-1 (ICAM-1), P-selectin, and nitrotyrosine [19].

Heme oxygenase- 1 (HO-1) has been reported to mediate anti-inflammatory and cytoprotective activity [20]. Pae and colleagues [21] have reported that the production of TNF- $\alpha$ and IL-6 in LPS-stimulated RAW264.7 cells was decreased by treatment with costunolide, which increased the expression and activity of HO-1 via enhanced nuclear accumulation of a redox-regulated transcription factor, nuclear factor erythroidrelated factor-2 (Nrf2). Pretreatment with a HO-1 inhibitor abrogated the inhibitory effect of costunolide on LPS-induced TNF- $\alpha$ and IL- 6 production [21]. CD4 ${ }^{+}$T cell activation and proper differentiation into T helper (Th) cells are important for establishing an adaptive immune response against foreign pathogens. However, an excessive activation of Th cells leads to inflammation and autoimmune diseases [22]. When $\mathrm{CD} 4^{+} \mathrm{T}$ cells were induced to differentiate, costunolide markedly reduced the differentiation into a population of Th1, Th2, and Th17 subsets. Costunolide also inhibited the expression level of Th subset-polarizing master genes such as T-bet, GATA3, and ROR $\gamma$ t. The compound reduced the level of $\mathrm{CD} 4^{+} \mathrm{T}$ cell activation marker $\mathrm{CD} 69$ and attenuated $\mathrm{T}$ cell proliferation by blocking phosphorylation of extracellular signal-regulated kinase (ERK) and p38 MAPK [23].

\subsection{Anti-Allergic Effects of Costunolide}

Chemokines play an important role in inducing various allergic and inflammatory skin diseases, such as atopic dermatitis, psoriasis, and eczema. Keratinocytes are known to respond to various chemokines, such as chemokine (C-C motif) ligand (CCL)-17 (also known as TARC), CCL-22 (alternatively known as MDC), CCL-5 (synonym RANTES), and IL-8, which are involved in precipitating atopic dermatitis [24]. Costunolide significantly reduced mRNA expression of various chemokines including TARC/CCL17, MDC/CCL22, RANTES/CCL5, and IL-8 in HaCaT cells stimulated with TNF- $\alpha$ and IFN- $\gamma$ [25]. In the OVA-induced asthmatic mouse model, costunolide reduced eosinophil infiltration, inflammation score, and mucin secretion in the lungs. In particular, the increase of eosinophil count in BALF (bronchoalveolar lavage fluid) by OVA was significantly inhibited by costunolide. Moreover, the compound decreased the expression and secretion of Th2 cytokines (IL-4 and IL-13) in BALF and lung tissue [26]. Costunolide reduced the activity of $\beta$-hexosaminidase, an enzyme involved in mast cell degranulation, and decreased IL-4 mRNA transcript in IgE-sensitized rat basophilic leukemia (RBL-2H3) cells. In addition, the inhibition of IL-5-dependent growth of Y16 pro-B cells suggests the potential of costunolide or its derivatives to be developed as mast cell stabilizers and pro-B cell proliferation inhibitors in allergic diseases [26,27].

\subsection{Costunolide in Bone Remodeling}

Osteoporosis, a disease of the bone generally characterized by excessive bone resorption due to poor osteoblastic and enhanced osteoclastic activity, is very common among the elderly population. Although few therapeutic interventions, such as the use of calcium and vitamin D3, parathyroid hormone analogs, bisphosphonates, and monoclonal antibodies, are current clinical recommendations, there is emerging need of developing new drugs [28]. Several studies have demonstrated the potential of costunolide in improving bone health. Costunolide stimulated the growth and differentiation of murine osteoblastic cells (MC3T3-E1) cells, as characterized by increased alkaline phosphatase (ALP) activity, collagen deposition and mineralization. These osteoblastic activity of costunolide 
was abrogated by cotreatment with pharmacological inhibitors of either estrogen receptor (ER) or phoaphatidylinositol-3-kinase (PI3K), suggesting that the increased mineralization by the compound was associated with increased activation of ER and PI3K [29]. Likewise, costunolide increased the ALP activity and matrix mineralization, and elevated the transcription of a number of differentiation factors, such as distal-less homeobox 5 (Dlx5), runt-related transcription factor 2 (Runx2), and osteocalcin (OC) in mouse mesenchymal stem cell (C3H10T1/2) by stimulating activated transcription factor 4 (ATF4)-dependent increased expression and activity of HO-1. The blockade of HO-1 by treating cells with tin (IV) protoporphyrin IX dichloride (SnPP) blocked costunolide-induced Runx2 expression, suggesting that costunolide-induced osteoblast differentiation is regulated by ATF4-dependent HO-1 expression [30]. The receptor activator of nuclear factor kappa-B ligand (RANKL) induces the differentiation of bone marrow-derived macrophages into osteoclasts, a key mediator of bone resorption. Treatment with costunolide inhibited osteoclast differentiation by blocking the expression of nuclear factor of activated T cells, cystoplasic-1 (NFATc1) through the inhibition of c-Fos transcriptional activity, without affecting c-Fos expression. The compound also attenuated the mRNA expression of tartrate-resistant acid phosphatase (TRAP) and osteoclast-associated receptor (OSCAR) (Figure 2). Thus, costunolide inhibited RANKL-induced osteoclast differentiation by inhibiting c-Fos transcriptional activity [31].

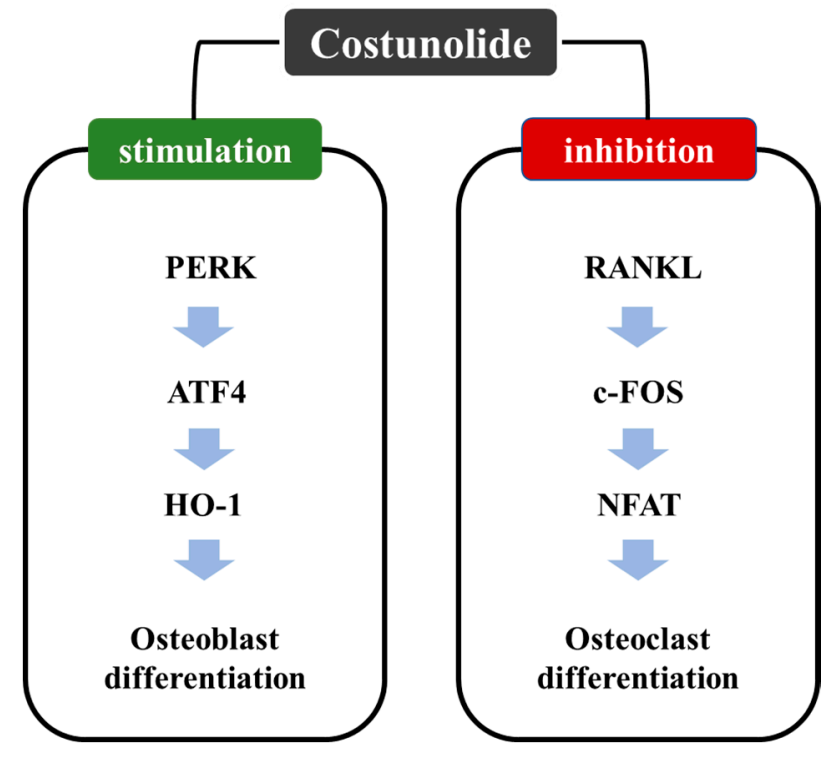

Figure 2. Effect of costunolide on differentiation of osteoblast and osteoclast. Costunolide induces osteoblast differentiation through ATF-4-induced HO-1 expression in mesenchymal stem cells. On the other hand, costunolide suppressed RANKL-mediated osteoclast differentiation via inhibiting RANKL-mediated c-Fos transcriptional activity in bone marrow cells.

\subsection{Costunolide as a Neuroprotective Agent}

Parkinson disease (PD) is one of the neurodegenerative diseases characterized by reduced dopaminergic (DAergic) neuronal transmission in the substantia nigra (SN). One of the key regulators of DAergic nerve transmission, especially the regeneration of synaptic vesicles, and the storage, metabolism, and release of DA at nerve endings is $\alpha$-synuclein (ASYN), which is transcriptionally regulated by nuclear receptor related-1 (Nurr1). In PD patients with Nurr1 mutations, Nurr1 expression was decreased and ASYN expression was increased. Whereas the expression of the Nurr1 gene is essential for the development and maintenance of nigral DAergic neurons, overexpression of ASYN causes selective degeneration and toxicity of DAergic neurons. Nurr1 also participates in DA metabolism by regulating vesicular monoamine transporter type 2 (VMAT2) and dopamine transporter (DAT) [32]. Ham et al demonstrated that costunolide inhibited DA-induced apoptosis of 
human neuroblastoma (SH-SY5Y) cells which was associated with decreased ASYN expression and the restoration of DA-mediated reduced Nurr1, VMAT2, and DAT level [33]. These results suggest the potential of costunolide in the management of PD. Since oxidative stress-mediated neuronal cell death is a well-known cause of many neurodegenerative diseases, the reduction of reactive oxygen species (ROS) can be a pragmatic approach to delay the disease progression. Treatment with costunolide inhibited $\mathrm{H}_{2} \mathrm{O}_{2}$-induced apoptosis of $\mathrm{PC} 12$ cells by reducing intracellular ROS, stabilizing mitochondrial membrane potential (MMP), and decreasing the caspase-3 activity (Figure 3). Moreover, costunolide reduced $\mathrm{H}_{2} \mathrm{O}_{2}$-induced cell death by blocking the phosphorylation of p38 MAPK and ERK [12]. Besides oxidative stress, persistent inflammation often leads to neurodegeneration. By virtue of its anti-inflammatory properties costunolide inhibited LPS-induced apoptosis of BV2 microglial cells by decreasing the expression of a series of neuroinflammatory mediators, such as TNF- $\alpha$, IL-1, IL-6, iNOS, macrophage chemoattractant protein-1 (MCP-1), and COX-2 via the inhibition of NF-kB and MAPK activation [34].

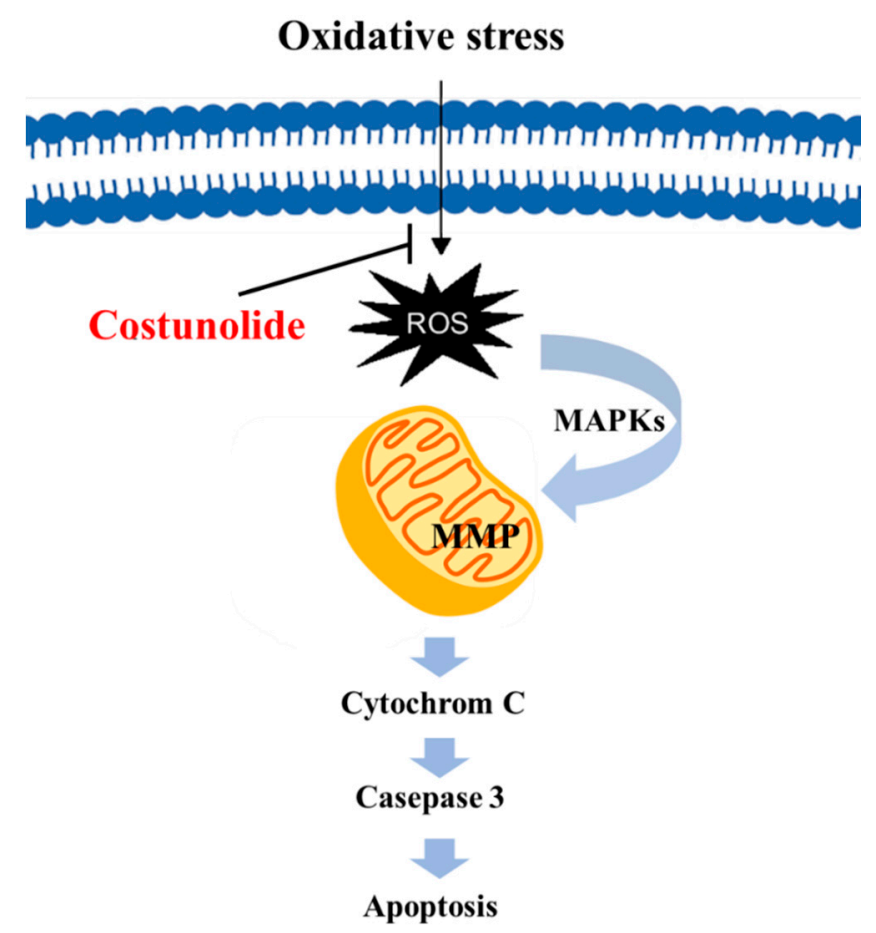

Figure 3. The effect of costunolide on apoptosis of neurons. Costunolide reduced intracellular ROS caused by oxidative stress. As a result, mitochondrial membrane potential (MMP) stabilized and apoptosis-related proteins such as caspase 3 decreased.

\subsection{Antimicrobial Properties of Costunolide}

Several studies have demonstrated the antimicrobial activity of costunolide (Table 1). The antibacterial activity of costunolide against Mycobacterium tuberculosis $\mathrm{H} 37 \mathrm{Rv}$ (M. tuberculosis) [35] and Mycobacterium avium (M. avium) [36] in fluorometric Alamar Blue microassay and radiorespirometric bioassay, respectively, suggest that the compound may be considered for developing antitubercular drugs. In addition, in vitro agar diffusion test showed that costunolide exhibited antimicrobial activity against Staphylococcus aureus (S. aureus), Escherichia coli (E. coli), and Pseudomonas aeruginosa (P. aeruginosa) [37]. Costunolide also inhibited the growth of H. pylori [38], which is causally linked with gastric and duodenal ulcers. In vitro disc diffusion assay revealed that costunolide inhibited the growth of various pathogenic fungi, such as Trichophyton mentagrophytes, T. simum, T. rubrum, Epidermophyton floccosum, Scopulariopsis sp., Aspergillus niger, Curvulari lunata, Magnaporthe grisea, and Candida albicans [39]. Costunolide also showed antifungal activity against Botauttis cinereal, Colletotrichum acutatum, Colletotrichum fragariae and Colletotrichum gloeosporioides [40], and C. echinulata [41]. The 
antiviral property of costunolide was evident from the inhibition of hepatitis B surface antigen (HBsAg) expression in human hepatoma Hep3B cells and that of hepatitis B e antigen ( $\mathrm{HBeAg})$, a hepatitis B virus genome replication marker, in human hepatocytes and HepA2 cells [42].

Table 1. Antimicrobial activity of costunolide.

\begin{tabular}{|c|c|c|c|c|}
\hline Effect & Tested Orga & & Concentration & Reference \\
\hline \multirow{7}{*}{$\begin{array}{l}\text { Antibacterial } \\
\text { activity }\end{array}$} & M. tuberculosis & $\mathrm{MIC}(\mathrm{mg} / \mathrm{L})$ & 12.5 & [35] \\
\hline & S. aureus & \multirow{3}{*}{ MIDZ (mm) } & 18 & \multirow{3}{*}{ [37] } \\
\hline & E. coli & & 19 & \\
\hline & P. aeruginosa & & 14 & \\
\hline & M. avium & \multirow{2}{*}{$\mathrm{MIC}(\mu \mathrm{g} / \mathrm{mL})$} & 128 & \multirow{2}{*}[36]{} \\
\hline & M. tuberculosis & & 32 & \\
\hline & H. pylori & MIC ( $\mu \mathrm{g} / \mathrm{mL})$ & $100-200$ & [38] \\
\hline \multirow{10}{*}{ Antifungal activity } & Trichophyton mentagrophytes & & & \\
\hline & T. simum & & $\begin{array}{c}62.5 \\
62\end{array}$ & \\
\hline & T. rubrum & & 31 or 62 & \\
\hline & Epidermophyton floccosum & MIC $(\mu \mathrm{g} / \mathrm{mL})$ & 125 & [39] \\
\hline & $\begin{array}{l}\text { Scopulartopsis sp. } \\
\text { Aspergillus niger }\end{array}$ & & 250 & \\
\hline & $\begin{array}{l}\text { Aspergillus niger } \\
\text { Curvulari lunata }\end{array}$ & & 125 & \\
\hline & Magnaporthe grisea & & 250 & \\
\hline & Colletotrichum acutatum & \multirow{2}{*}{ MDIZ (mm) } & 4 & \multirow{2}{*}[40]{} \\
\hline & Colletotrichum fragariae & & 6 & \\
\hline & C. echinulata & $\mathrm{EC}_{50}(\mu \mathrm{g} / \mathrm{mL})$ & 6 & [41] \\
\hline Antiviral activity & Hepatitis B virus (HBV) & $\mathrm{IC}_{50}(\mu \mathrm{M})$ & 1 & [42] \\
\hline
\end{tabular}

Lipoteichoic acid (LTA)-induced acute lung injury (ALI) in mice is a model to represent experimental pneumonia. Treatment with costunolide significantly reduced LTA-induced inflammatory cell infiltration and lung tissue damage by decreasing the production of various cytokines and chemokines. Moreover, the compound inhibited LTA-induced iNOS expression in mouse bone marrow-derived macrophages by blocking phosphorylation of TAK1, p38 MAPK, and ERK, without affecting the activation of NF- $\mathrm{KB}$ [43]. Thus, costunolide may be considered as a lead compound for developing novel antimicrobial agents.

\subsection{Costunolide in the Treatment of Alopecia}

The cosmetic use of herbal products, especially for preventing hair loss or promoting hair growth, have long been practiced throughout the world. The herbal therapies used as hair growth promoters are expected to have low toxicity, be easy to use, low cost, and have high patient compliance. As the physiological and biochemical pathways in hair follicle dermal papillary cells (hHFDPCs) are unfolded, the mechanistic basis of hair growth promotion by many natural products is being explored [44,45]. It has been reported that topical application of costunolide significantly improved hair growth in C57BL/6 mice in vivo and promoted the proliferation of hHFDPCs in vitro [46]. Mechanistically, costunolide inhibited $5 \alpha$-reductase activity and suppressed transforming growth factor (TGF- $\beta 1$ ) induced phosphorylation of Smad-1/5 (mothers against decapentaplegic-1/5) in hHFDPCs, whereas the compound increased the levels of $\beta$-catenin and Gli1 mRNA and protein [46]. Thus, the development of costunolide-based formulation for the treatment of alopecia would be an interesting approach pending further studies on the toxicity and pharmacokinetic properties of the compound. 


\subsection{Costunolide as an Anticancer Agent}

The search for anticancer agents from natural sources, especially plants, has led to the discovery of many clinically useful drugs. Extensive investigation of the anticancer effects of costunolide have shown that the compound induces apoptosis and inhibits proliferation of various cancer cells in vitro, and suppresses angiogenesis and metastasis. The following section will shed light on the biochemical processes and molecular targets of costunolide in exerting its anticancer effects.

\subsubsection{Inhibition of Cell Proliferation}

Costunolide decreased the proliferation of various cancer cells including those of the colon, breast, prostate, liver, gastric, and blood cancer cells [47-51]. Treatment of HCT-116 cells with costunolide decreased cell proliferation by inhibiting phosphorylation of mammalian target of rapamycin (mTOR) and its downstream kinases p70S6K and 4E-BP1, and increasing the phosphorylation and nuclear localization of p53 [52]. The antiproliferative effect of costunolide was mediated, at least in part, through suppression of cellular glutaminolysis via blockade of the promoter activity of glutaminase 1 (GLS1). The compound also decreased GLS1 mRNA and protein expression in p53-dependent manner since pretreatment with a p53 inhibitor reversed costunolide-mediated suppression of GLS1 activity and expression [52]. The antiproliferative effect of costunolide in MCF-7 cells was associated with microtubule polymerization and alteration of spindle morphology. [47].

Several other studies have reported that costunolide inhibits various tumor cell proliferation by blocking G2/M phase of the cell cycle and modulating the effect of cyclins and cyclin-dependent kinases (Cdk) $[51,53,54]$. The growth inhibition of SW-480 cells upon treatment with costunolide was associated with the downregulation of cyclin D1 and survivin, which was mediated via inhibition of nuclear translocation of $\beta$-catenin and its co-activator molecule galectin-3 [49]. Peng et al. [55] reported that costunolide induced cell cycle arrest at G2/M phase in MCF-7 and MDA-MB-231 cells via activation of p53 and p-14-3-3 expression and inhibition of c-Myc, p-AKT, and p-BID expression. Moreover, the ratio of BAX/BCL-2 was significantly increased upon costunolide treatment, which led to the induction of apoptosis in these cells [55]. Another study showed that costunolide-induced G2/M cell cycle arrest in MDA-MB-231 cells, which was mediated through the inhibition of Cdc2 and cyclin B1, and the elevation of $\mathrm{p} 21^{\mathrm{WAF} 1}$ expression was independent of p53 activation [56]. Roy and colleagues have demonstrated that the G2/M phase of cell cycle arrest in MCF-7 and MDA-MB-231 cells incubated with costunolide was mediated through the downregulation of cell cycle regulatory proteins, such as cyclin D1, D3, CDK-4, CDK-6, p18 ${ }^{\mathrm{INK} 4 \mathrm{c}}, \mathrm{p} 21^{\mathrm{CIP} 1 / \text { Waf-1 }}$, and p27 ${ }^{\mathrm{KIP} 1}$. However, the compound did not affect the proliferation of normal mammary epithelial (MCF-10A) cells [57]. Likewise, the increase level of p21 ${ }^{\mathrm{WAF} 1}$ and reduced expression of cyclin B1 and CDK2 by costunolide led to the G2/M phase arrest in K562 cells. According to this study, the compound enhanced imatinib-induced apoptosis in K562 cells via modulation of B cell receptor (Bcr)/Abl and STAT5 signaling pathways. In another study, these authors reported that costunolide sensitized K562 cells to doxorubicin via inhibition of the PI3K/Akt activity [58]. In another study, costunolide arrested the cell cycle at the G2/M phase through the downregulation of Chk2/Cdc25c/Cdk1/cyclin B1 signaling in human hepatoma HA22T and VGH cells [51]. Incubation of human prostate cancer (PC-3, DU-145, and LNCaP) cells with costunolide arrested the cell cycle at the G1 phase, which was associated with the inhibition of the CDK2 activity and $\mathrm{Rb}$ phosphorylation [50]. Moreover, costunolide upregulated p53 and p21 expression in human esophageal squamous Eca-109 cells, thereby inducing G1/S phase arrest [59].

\subsubsection{Induction of Apoptosis}

\section{Mitochondria-Mediated Apoptosis}

Costunolide induced mitochondria-mediated apoptosis as evidenced by the inhibition of Bcl-2, induction of Bax, and release of cytochrome $\mathrm{c}$ in human prostate (PC3 and DU-145) [60], leukemia (K562) [48], oral cancer (Eca-109) [59], gastric cancer (SGC-7901) [54], lung squamous carcinoma 
(SK-MES1) [53], and bladder cancer (T24) [61] cells. Treatment of PC3 and DU-145 cells with costunolide led to the generation of ROS, the phosphorylation of c-Jun-N terminal kinase (JNK) and p38 MAPK, the inhibition of Bcl-2 and Bcl-xl, and the induction of Bax, thereby leading to reduced mitochondrial membrane potential and cytochrome $c$ release and caspase 3 activation. The apoptosis induction by costunolide resulted in the reduced growth of PC3 cells xenograft tumors in nude mice [60]. Likewise, costunolide induced mitochondria-mediated apoptosis by upregulation of Bax, downregulation of Bcl-2, and activation of caspase-3 and poly ADP-ribose polymerase via ROS production and loss of mitochondrial membrane potential in oral cancer Eca-109 cells [59]. The compound also activated JNK in human leukemic U937 cells, thereby leading to mitochondrial cell death via phosphorylation of Bcl-2 and translocation of Bax to mitochondria [62]. Hua et al. demonstrated that the apoptosis of SK-MES-1 cells upon treatment with costunolide was mediated through upregulation of p53 and Bax expression, downregulation of Bcl-2 expression, and caspase-3 activation [53]. In addition to inducing Bax, caspase-3 and PARP cleavage in T24 bladder cancer cells, costunolide also attenuated expression of survivin and $\mathrm{Bcl} 2$ as a mechanism of apoptosis induction [61]. Costunolide induced mitochondrial-mediated apoptosis through activation of caspase-3, -8 , and -9 in ovarian cancer cell lines (MPSC1PT, A2780PT, and SKOV3PT) and the human endometriotic epithelial cells (11Z, 12Z) [63,64]. Furthermore, incubation of multidrug resistant ovarian cancer cells (OAW42-A) with costunolide attenuated cell growth with an $\mathrm{IC}_{50}$ of $25 \mu \mathrm{M}$, and induced apoptosis, which was mediated through induction of Bax, decreased the expression of Bcl-2 and cleavage of caspase- 3 and 9. Moreover, the compound induced autophagy as evidenced by the elevated expression of LC3 II and Beclin 1 [65].

\section{Endoplasmic Reticulum (ER) Stress-Mediated Apoptosis}

Apoptosis may result from continued ER stress that activates unfolded protein response (UPR) signaling pathways. Costunolide activated the ionositol requiring enzyme (IRE)- $1 \alpha$, a resident ER membrane protein, which further activated JNK by recruiting adapter molecules TRAF2 and ASK1 in cultured lung adenocarcinoma cell line A549 cells [66]. Costunolide-activated JNK led to Bcl-2 phosphorylation at serine 70 , a mechanism to convert antiapoptotic Bcl-2 to play proapoptotic functions, thereby causing cytochrome $c$ release, caspase- 3 activation, and PARP cleavage, leading to induction of apoptosis. Authors have further demonstrated that costunolide-induced ROS generation played a critical role in this process as pretreatment of cells with ROS scavenger $N$-acetyl cysteine abrogated costunolide-induced ER stress and apoptosis [66]. A similar mechanism of ROS-mediated ER stress induction by costunolide led to the expression of Bip and IRE $\alpha$, and the activation of the JNK pathway, leading to apoptosis in human osteosarcoma U2OS cells [67]. Recent studies have shown that the thioredoxin/thioredoxin reductase (TrxR) system causes tumor cell resistance to oxidative stress-induced apoptosis. Surface plasmon resonance analysis and molecular docking study revealed that costunolide directly interacted with TrxR1 via its lactone oxygen atom with Gln-494 of TrxR1 and inhibited the activity of TrxR1, thereby increasing the production of ROS and inducing ROS-dependent ER stress and apoptosis in colon cancer cells (HCT-116, SW-620, and HT-29 cells). This study also demonstrated that the compound arrested G2/M phase of cell cycle and attenuated the expression of cyclin B1, CDC2, MDM2, and Bcl2 and increased the expression of Bax and cleavage of caspase 3, which was reversed by cotreatment with $N$-acetyl cysteine, suggesting the involvement of ROS in costunolide-induced retardation of tumor cell growth. Furthermore, costunolide treatment of mice transplanted with colon cancer cells inhibited tumor growth and decreased TrxR1 activity and ROS levels [68].

\section{Death Receptor-Mediated Apoptosis}

Extrinsic mechanisms of apoptosis induction by costunolide have also been reported. The induction of apoptosis in estrogen receptor-negative human breast cancer (MDA-MB-231) cells by costunolide involves the activation of Fas, caspase-8, caspase-3, and the degradation of PARP [56]. Costunolide also increased the phosphorylation of Fas-associated death domain (FADD) at serine 194, leading to apoptotic cell death in human B cell lymphoma. [69]. 


\subsubsection{Telomerase Reverse Transcriptase (TERT) Inhibition}

Telomeres, which maintain genomic integrity in normal cells, are shortened upon each cell division, thus leading to chromosomal instability, cellular senescence, and aging. However, the length of the telomeres is maintained by high levels of telomerase enzyme present in tumor cells, thereby allowing cancer cells to be immortal. Therefore, telomerase has been considered as a possible target for cancer treatment [69]. It has been reported that costunolide caused significant inhibition of telomerase activity in human B cell leukemia (NALM-6) cells by decreasing the mRNA and protein expression of human telomerase reverse transcriptase (hTERT), which controls the enzymatic activity of telomerase, and induced apoptosis in these cells [68]. Likewise, costunolide showed strong inhibition of telomerase activity in MCF-7 and MDM-23-231 cells through the downregulation of hTERT mRNA via inactivation of c-Myc and Sp1 transcription factors [69]. The antiproliferative and apoptosis-inducing effects of costunolide was also associated with inhibition of hTERT in human glioma cells $[70,71]$ and human hepatocellular carcinoma (HepG2/C3A, PLC/PRF/5) (A172, U87MG) cells [72].

\subsubsection{Inhibition of Angiogenesis}

The persistent growth and spread of a tumor require a constant supply of nutrients and oxygen to the cancer cells. The formation of new blood vessels, a process known as angiogenesis, is therefore an essential step in tumor invasion and metastasis. The discovery of angiogenesis inhibitors (e.g., avastin) helps reduce the morbidity and mortality from various cancers. A key angiogenic molecule is vascular endothelial growth factor (VEGF), which by binding with VEGF receptors (VEGFR) on vascular endothelial cells promotes formation of new blood vessels [73].

In a murine cannulated sponge implant angiogenesis model, administration of costunolide to Swiss albino mice implanted with polyester polyurethane sponges used as a framework for fibroblast tissue growth reduced the levels of VEGF and hemoglobin content in fibrovascular tissue, suggesting the antiangiogenic property of the compound [74]. Jeong et al. reported that costunolide attenuated VEGF-induced proliferation and chemotaxis of human umbilical vein endothelial cells (HUVECs), and blocked VEGF-induced phosphorylation of KDR/Flk-1 in NIH 3T3 cells overexpressing KDR/Flk-1. In addition, VEGF-stimulated neovascularization in mouse corneal micropocket analysis was reduced by costunolide treatment [75]. In another study, costunolide significantly reduced VEGF secretion and decreased VEGF mRNA levels in human gastric cancer (AGS), colon cancer (Caco-2), and liver cancer (HepG2/C3A) cells. This study also reported that costunolide significantly reduced VEGFR1 and VEGFR2 expression at both mRNA and protein levels [76].

\subsubsection{Inhibition of Tumor Metastasis}

Cancer metastasis refers to the spread of tumor cells from their site of origin to other distant parts of the body. Metastasis consists of multistep processes including tumor cell spread, extracellular matrix (ECM) degradation, tumor cell invasion in ECM, angiogenesis, and secondary metastatic tumor growth [77]. Costunolide inhibited TNF- $\alpha$-induced migration and invasion of MDA-MB-231 breast cancer cells by downregulating the expression of matrix metalloproteinase (MMP)-9 gene via blockade of NF- $\mathrm{kB}$ activation. Moreover, the xenograft tumor growth of MBA-MB-231 cells in athymic nude mice was diminished upon treatment with costunolide [77]. The MMP-2 and MMP-9 are key molecules involved in tumor invasion and metastasis. Costunolide significantly inhibited invasion and decreased MMP-2 expression in human neuroblastoma (NB-39) cells [78]. The invasion of soft tissue sarcoma (TE-671, SW-872, and SW982) cells was also inhibited by costunolide via modulation of MMPs expression [79]. Of the various forms of metastasis, lymphatic metastasis is an important determinant in cancer therapy and staging. Costunolide inhibited the proliferation and capillary formation of TR-LE (temperature-sensitive mouse lymphoid endothelial cells) cells, suggesting that the compound can provide clinical benefits as an inhibitor of lymphoproliferative growth during tumor metastasis [80]. Epithelial-mesenchymal transition (EMT) is critical step in tumor invasion and metastasis. One of 
the mechanisms that the EMT process initiates in tumor invasion is the detyrosination of tubulin via inhibition of tyrosine ligase, and the detyrosinated tubulin forms microtentacles (McTN) which promotes tumor cell reattachment to the endothelial layer during tumor invasion. Costunolide significantly reduced detyrosinated tubulin and the frequency of McTN in multiple invasive breast tumors, thereby preventing tumor cells attachment with endothelial tissue and blocking invasion [81].

\subsection{Antidiabetic Effects of Costunolide}

An in vitro assay has revealed that the methanol extract of leaves of Costus speciosus inhibited $\alpha$-glucosidase activity with an IC $_{50}$ value of $67.5 \mu \mathrm{g} / \mathrm{ml}$ and attenuated $\alpha$-amylase activity with an $\mathrm{IC}_{50}$ value of $5.88 \mathrm{mg} / \mathrm{ml}$, which is lower than the reference compound acarbose [82]. Since costunolide is abundantly present in leaves of Costus speciosus, this study indicates the potential of costunolide in managing glycemic control. A subsequent study demonstrated that costunolide significantly reduced blood glucose level, glycosylated hemoglobin ( $\mathrm{HbA1c}$ ), serum total cholesterol, triglyceride, and LDL cholesterol level in streptozotocin (STZ)-induced diabetic rats [83]. Moreover, the compound remarkably increased plasma insulin, tissue glycogen, HDL cholesterol, and serum protein level [83]. Since oxidative stress affect the pathogenesis and progression of diabetic tissue injury, the induction of antioxidant enzymes, such as glutathione peroxidase, catalase, and superoxide dismutase in STZ-induced diabetic rat's pancreas indicates the role of costunolide in improving glycemic control in diabetes [8]. However, additional studies are warranted to ascertain the antidiabetic property of this compound.

\section{Pharmacokinetics and Toxicity Profile}

Pharmacokinetic studies are an integral part of the drug discovery process. The understanding of the absorption, distribution, metabolism, and elimination of the drug-to-be is an essential step in new drug development. There have been several studies reporting the pharmacokinetic profile of costunolide. The maximum plasma concentration $\left(C_{\max }\right)$ and time required to attain highest plasma level of the molecule $\left(\mathrm{T}_{\max }\right)$ after oral administration of costunolide to Wistar rats were found as $0.024 \pm 0.004 \mathrm{mg} / \mathrm{L}$ and $9.0 \pm 1.5 \mathrm{~h}$, respectively. The half-life $\left(\mathrm{t}_{1 / 2}\right)$ and area under the curve (AUC) were $4.97 \mathrm{~h}$ and $0.33 \pm 0.03 \mathrm{mg} \cdot \mathrm{h} / \mathrm{mL}$, respectively [84]. However, a subsequent study reported that after oral administration of costunolide to Wistar rats, the $C_{\max }$ and $T_{\max }$ were $19.84 \mathrm{ng} / \mathrm{mL}$ and $10.46 \mathrm{~h}$, respectively, and the half-life $\left(\mathrm{t}_{1 / 2}\right)$ and AUC were $5.54 \mathrm{~h}$ and $308.83 \mathrm{ng} \cdot \mathrm{h} / \mathrm{mL}$, respectively [85]. According to a recent study, oral administration of costunolide to SD rats showed $C_{\max }, T_{\max }, t_{1 / 2}$, and AUC as $0.106 \pm 0.045 \mu \mathrm{g} / \mathrm{mL}, 8.00 \mathrm{~h}, 14.62 \pm 3.21 \mathrm{~h}$, and $1.23 \pm 0.84 \mu \mathrm{g} \cdot \mathrm{h} / \mathrm{mL}$, respectively [86]. The large variation in pharmacokinetic parameters between these studies may be due to the use of different assay techniques and/or animal models. In addition, intravenous administration of costunolide to Sprague-Dawley rats revealed the $C_{\max }$ as $12.28 \pm 1.47 \mu \mathrm{g} / \mathrm{mL}$, and the half-life $\left(\mathrm{t}_{1 / 2}\right)$ and AUC were detected as $1.16 \pm 0.06 \mathrm{~h}$ and $3.11 \pm 0.13 \mu \mathrm{g} \cdot \mathrm{h} / \mathrm{mL}$, respectively [87]. These results would have immense importance in further development of costunolide-based therapy.

Although costunolide has been examined extensively for its therapeutic potential in various animal models as discussed in the previous sections of this review, acute and chronic toxicity studies are scarce. A recent study demonstrated that the compound induced apoptosis in normal Chinese hamster ovarian cells by inducing clastogenic and genotoxic effects as evidenced by micronuclei formation and chromosomal breaks [88]. Thus, more rigorous toxicity studies to determine the lethal dose $\left(\mathrm{LD}_{50}\right)$ and ensure safety of the compounds is of paramount importance in further progressing the development of costunolide as a drug candidate.

\section{Conclusions}

Sesquiterpene lactones form a large, structurally diverse group of natural products found almost universally in plants. Extensive investigation of the therapeutic potential of sesquiterpene lactones has yielded important candidates for pharmaceutical development [89]. Costunolide is a well-known 
sesquiterpene lactone, which has been isolated from various plant species. As has been discussed in earlier sections, costunolide has been reported to possess antioxidant, anti-inflammatory, antiallergic, bone remodeling, neuroprotective, antimicrobial, hair growth promoting, anticancer, and antidiabetic properties (Figure 4 and Table 2). Limited pharmacokinetic studies have also shown that the compound can be bioavailable. However, the majority of these studies have been conducted in cultured cells or using an in vitro system. Considering the therapeutic value of the compound, it would be interesting to further examine the effects of costunolide in various other animal models to reveal the subacute and chronic toxicities, detailed elucidation of molecular mechanisms of action, and structural modifications to develop new therapeutics based on costunolide or its derivatives.

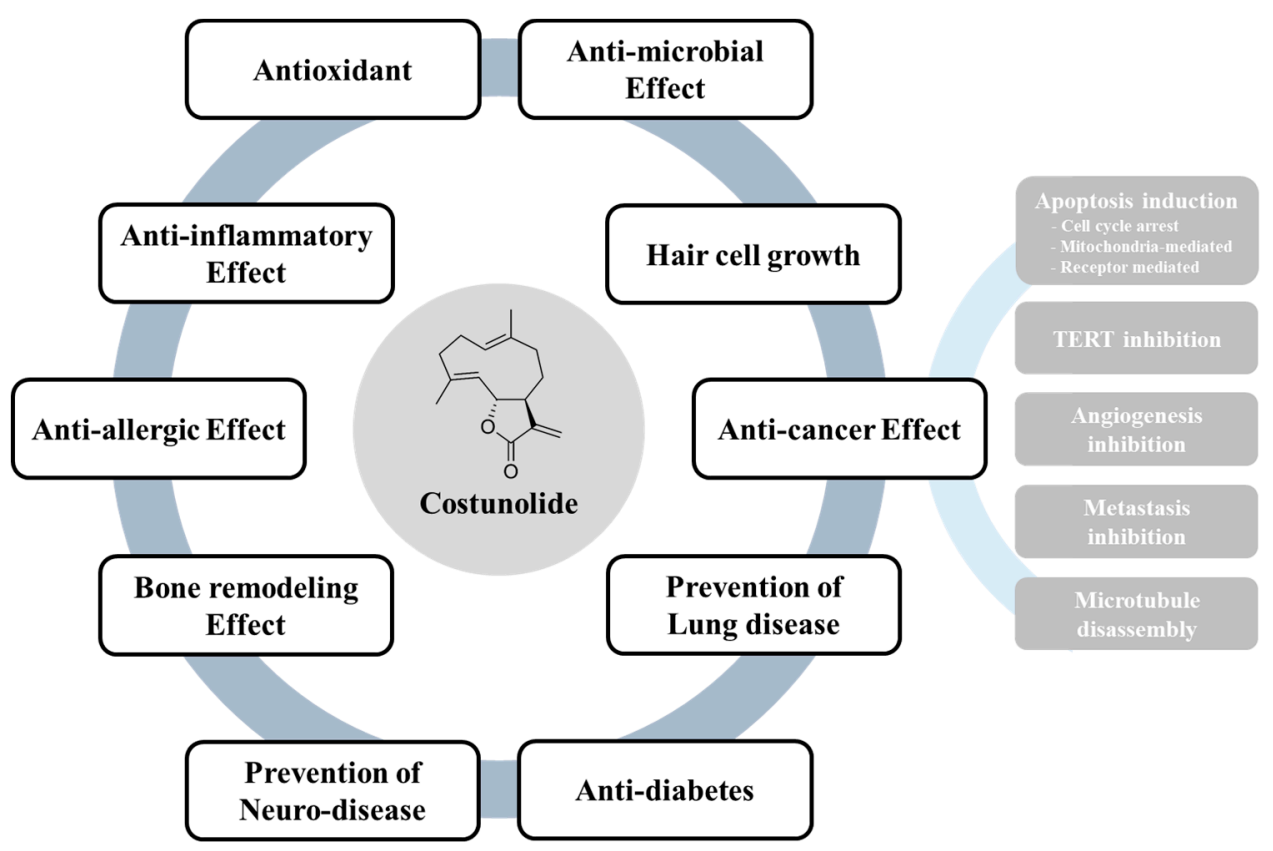

Figure 4. Bioactivities of costunolide. Costunolide could exert its therapeutic potential including antioxidant, anti-inflammatory effect, anti-allergic effect, bone remodeling effect, prevention of neurodegenerative disease, anti-microbial effect, inhibition of alopecia, prevention of lung disease and anti-diabetic effect. In particular, costunolide elicits anti-cancer activities partly through induction of apoptosis, Inhibition of cell proliferation, TERT, angiogenesis, metastasis and microtubule disassembly. 
Table 2. Molecular mechanisms underlying bioactivities of costunolide.

\begin{tabular}{|c|c|c|c|c|}
\hline Type & Experimental Model & Dose/Concentration & Mechanism of Action & Ref. \\
\hline \multirow{4}{*}{ Antioxidant effect } & STZ-induced diabetic rats & $20 \mathrm{mg} / \mathrm{kg}$ day & Decreased in TBARS level; increased in GSH content & [8] \\
\hline & MCF-7, MDA-MB-231 & $20,40 \mu \mathrm{M}$ & Decreased in TBARS level; increased in SOD, catalase, GPx activity & [10] \\
\hline & 5-FU-induced IM & $5,20 \mathrm{mg} / \mathrm{kg}$ & Increased in SOD level & [11] \\
\hline & $\mathrm{H}_{2} \mathrm{O}_{2}$-stimulated PC12 cells & $50,100 \mu \mathrm{M}$ & Decreased intracellular ROS & [12] \\
\hline \multirow{10}{*}{$\begin{array}{l}\text { Anti-inflammatory } \\
\text { effect }\end{array}$} & Cg-induced edema; LPS-induced fever & $0.015,0.15,0.3 \mathrm{mg} / \mathrm{kg}$ & Inhibited edema formation; Reduced the fever index & [13] \\
\hline & LPS-stimulated RAW264.7 cells & $0.5,1.5,3 \mu \mathrm{g} / \mathrm{ml}$ & $\begin{array}{l}\text { Inhibited NF-kB activity, phosphorylation of I } \mathrm{K} B \alpha \text { and NO } \\
\text { production; suppressed iNOS mRNA expression }\end{array}$ & {$[14]$} \\
\hline & 5-FU-induced IM & $5,20 \mathrm{mg} / \mathrm{kg}$ & Decreased the expression of iNOS, COX-2, TNF- $\alpha$ and NO & [11] \\
\hline & IL-22 or IFN- $\gamma$-stimulated keratinocytes & $12.5 \mu \mathrm{M}$ & Inhibited STAT1/3 phosphorylation & [15] \\
\hline & IL-6-stimulated THP-1 cells & $6,12,25 \mathrm{ng} / \mathrm{ml}$ & Inhibited STAT3 and JAK1/2 phosphorylation & [16] \\
\hline & Ethanol-induced gastric ulcer & $5,20 \mathrm{mg} / \mathrm{kg}$ & Suppressed the activation of NF- $\mathrm{kB}, \mathrm{TNF}-\alpha, \mathrm{COX}-2, \mathrm{NO}$ and iNOS & [17] \\
\hline & LPS-stimulated RAW264.7 cells & $0.1,0.3,1,3 \mu \mathrm{M}$ & $\begin{array}{l}\text { Suppressed the protein and mRNA expression of IL- } 1 \beta \text {; inhibited the } \\
\text { activity of AP-1 and the phosphorylation of MAPKs }\end{array}$ & [18] \\
\hline & Carrageenan-induced pleurisy & $5,10,15 \mathrm{mg} / \mathrm{kg}$ & $\begin{array}{l}\text { Reduced accumulation of PMNs and expression of T TNF- } \alpha \text {, ICAM-1, } \\
\text { P-selectin and nitrotyrosine }\end{array}$ & [19] \\
\hline & LPS-stimulated RAW264.7 cells & $0.1,0.5,1 \mu \mathrm{M}$ & $\begin{array}{l}\text { Induced HO-1 expression and Nrf2 nuclear accumulation; inhibited } \\
\text { production of TNF- } \alpha \text { and IL- } 6\end{array}$ & [21] \\
\hline & CD3/CD28-stimulated CD4 ${ }^{+} \mathrm{T}$ cells & $0.5,1,2 \mu \mathrm{M}$ & $\begin{array}{l}\text { Inhibited the expression of T-bet, GATA3 and ROR } \gamma \mathrm{t} \text {; suppressed the } \\
\text { proliferation of } \mathrm{CD} 4^{+} \mathrm{T} \text { cells and expression of CD69; decreased the } \\
\text { phosphorylation of ERK and p38 }\end{array}$ & [23] \\
\hline \multirow{5}{*}{ Antiallergic effect } & TNF- $\alpha /$ IFN- $\gamma$-stimulated HaCaT cells & $2.5,5,10 \mu \mathrm{M}$ & Inhibited the expression of TARC, MDC, RANTES and IL-8 & [25] \\
\hline & IgE-sensitized RBL-2H3 & $10 \mu \mathrm{M}$ & Inhibited the expression of $\beta$-hexosaminidase & \multirow{2}{*}{ [26] } \\
\hline & OVA-induced mouse asthma model & $10 \mathrm{mg} / \mathrm{kg}$ & $\begin{array}{l}\text { Reduced eosinophil filtration, inflammation score and mucin } \\
\text { secretion; decreased the expression of IL- } 4 \text { and IL-13 }\end{array}$ & \\
\hline & Ketotifen-stimulated RBL-2H3 & $0.32,1.6,8,40 \mu \mathrm{M}$ & Inhibited the release of $\beta$-hexosaminidase & \multirow{2}{*}{ [27] } \\
\hline & IL-5-stimulated Y16 cells & $0.16,0.8,4,20,40 \mu \mathrm{M}$ & Inhibited the proliferation Y16 cells & \\
\hline \multirow{3}{*}{ Bone remodeling } & MC3T3-E1 cells differentiation & $10 \mu \mathrm{M}$ & Increased ALP activity, collagen deposition and mineralization & [29] \\
\hline & C3H10T1/2 cells differentiation & $1,10,10^{2}, 10^{3}, 10^{4} \mathrm{ng} / \mathrm{ml}$ & $\begin{array}{l}\text { Increased the expression of Dlx5, Runx2, ALP, and OC; reduced the } \\
\text { activity of ATF4 and expression of HO-1 }\end{array}$ & {$[30]$} \\
\hline & RANKL-induced osteoclast differentiation & $5 \mu \mathrm{M}$ & Suppressed NFATc1 expression and c-Fos activity & [31] \\
\hline
\end{tabular}


Table 2. Cont.

\begin{tabular}{|c|c|c|c|c|}
\hline Type & Experimental Model & Dose/Concentration & Mechanism of Action & Ref. \\
\hline \multirow{2}{*}{ Neuroprotective agent } & DA-stimulated SH-SY5Y & $0.8,4,2 \mu \mathrm{M}$ & $\begin{array}{c}\text { Decreased the expression of ASYN; increased the expression of } \\
\text { Nurr1, VMAT2 and DAT }\end{array}$ & [33] \\
\hline & LPS-stimulated BV2 microglial cells & $1 \mu \mathrm{M}$ & $\begin{array}{l}\text { Attenuated the expression of TNF- } \alpha \text {, IL-1,6, iNOS, MCP-1 and } \\
\text { COX-2; inhibited the activation of NF-KB }\end{array}$ & [34] \\
\hline \multirow{2}{*}{ Treatment of alopecia } & Testosterone-stimulated hHFDPCs & $3 \mu \mathrm{M}$ & Promotes the growth of hHFDPCs; inhibits the $5 \alpha$-reductase activity & \multirow{2}{*}{ [46] } \\
\hline & Hair growth in mice & $3 \mu \mathrm{M} / \mathrm{L}$ & Improved the hair growth & \\
\hline \multirow{13}{*}{$\begin{array}{l}\text { Inhibition of } \\
\text { proliferation }\end{array}$} & MCF-7 breast cancer cells & $10,100 \mathrm{nM}$ & Inhibited the cell growth; stimulated tubulin assembly & [47] \\
\hline & K562 leukemia cells & $15 \mu \mathrm{M}$ & Induced cell cycle arrest; induced apoptosis & [48] \\
\hline & S480 colon cancer cells & $5 \mu \mathrm{M}$ & $\begin{array}{l}\text { Suppressed cyclin D1, survivin, } \beta \text {-catenin, and galectin-3; inhibited } \\
\text { proliferation and survival of cells }\end{array}$ & [49] \\
\hline & LNCaP, PC-3, DU-145 prostate cancer cells & $1.3 \mu \mathrm{M}$ & Inhibited cell proliferation; induced cell cycle arrest at the G1phase & [50] \\
\hline & HA22T/VGH hepatocellular carcinoma cells & $5 \mu \mathrm{M}$ & $\begin{array}{l}\text { Caused G2/M arrest; up-regulated phosphorylation of Chk2, Cdc25c, } \\
\text { Cdk1, and cyclin B1 }\end{array}$ & [51] \\
\hline & HCT-116 colorectal cancer cells & $10,20,40 \mu \mathrm{M}$ & $\begin{array}{l}\text { Inhibited proliferation; suppressed mTOR phosphorylation and } \\
\text { GLS1 activity }\end{array}$ & [52] \\
\hline & SK-MES-1 lung squamous carcinoma cells & $40,80 \mu \mathrm{M}$ & $\begin{array}{l}\text { Inhibited growth of cells; induced cell cycle arrest at G1/S phase; } \\
\text { upregulated expression of p53 and Bax; downregulated Bcl-2 } \\
\text { expression; activated caspase-3 }\end{array}$ & [53] \\
\hline & SGC-7901 gastric adenocarcinoma cells & $20,40 \mu \mathrm{M}$ & Arrested cell cycle at G2/M phase; activated caspase-3 & [54] \\
\hline & MCF-7, MDA-MB-231 breast cancer cells & $0.9,1.3,2.2 \mu \mathrm{g} / \mathrm{mL}$ & $\begin{array}{l}\text { Arrested cell cycle at G2/M phase; induced p53 and 14-3-3 expression; } \\
\text { inhibited c-Myc, p-Akt and p-BID expression }\end{array}$ & [55] \\
\hline & MDA-MB-231 breast cancer cells & $15 \mu \mathrm{M}$ & $\begin{array}{l}\text { Induced G2/M cell cycle arrest; upregulated p21WAF1 expression; } \\
\text { inhibited cdc2 and cyclin B1 expression }\end{array}$ & [56] \\
\hline & MCF-7, MDA-MB-231 breast cancer cells & $40 \mu \mathrm{M}$ & $\begin{array}{l}\text { Arrested cell cycle arrest at G2/M phase; inhibited the expression of } \\
\text { cyclin D1, D3, CDK-4, CDK-6, p18 INK4c, p21 CIP1/Waf-1 and p27 } \\
\text { KIP1 }\end{array}$ & [57] \\
\hline & K562/ADR chronic myeloid leukemia cells & $0.1,1,10,100 \mu \mathrm{M}$ & Sensitized K562 cells to doxorubicin; inhibited PI3K/Akt activity & [58] \\
\hline & Eca-109 human esophageal cancer cells & $40,80 \mu \mathrm{M}$ & $\begin{array}{l}\text { Induced cell cycle arrest in G1/S phase; upregulated the expression of } \\
\text { p53, p21, Bax and caspase-3; downregulated Bcl-2 }\end{array}$ & [59] \\
\hline
\end{tabular}


Table 2. Cont.

\begin{tabular}{|c|c|c|c|c|}
\hline Type & Experimental Model & Dose/Concentration & Mechanism of Action & Ref. \\
\hline \multirow{6}{*}{$\begin{array}{l}\text { Mitochondria-mediated } \\
\text { apoptosis }\end{array}$} & PC-3, DU-145 prostate cancer cells & $20 \mu \mathrm{M}$ & $\begin{array}{l}\text { Enhanced doxorubicin to change of MMP; increased Bax expression } \\
\text { and cytochrome c release }\end{array}$ & {$[60]$} \\
\hline & T24 human bladder cancer cells & $25,50 \mu \mathrm{M}$ & $\begin{array}{l}\text { Increased expression of Bax, downregulated Bcl-2 and surviving; } \\
\text { activated caspase-3 and PARP }\end{array}$ & {$[48]$} \\
\hline & U937 human promonocytic leukemia cells & 5,10 & $\begin{array}{l}\text { Increased the activation of JNK; inhibited the expression of Bcl-2; } \\
\text { induced DNA fragmentation }\end{array}$ & [61] \\
\hline & SKOV3, A2780, MPSC 1 ovarian cancer cells & $10,20,30 \mu \mathrm{M}$ & $\begin{array}{l}\text { Triggered the activation of caspase- } 3,-8 \text {, and }-9 \text {; down-regulated Bcl-2 } \\
\text { expression, }\end{array}$ & [62] \\
\hline & 11Z human epithelial endometriotic cells & $\mathrm{IC}_{50} 14.21 \mu \mathrm{M}$ & $\begin{array}{l}\text { Induced the activation of caspase- } 3,-8 \text {, and }-9 \text {; inhibited the } \\
\text { activation of Akt and NF-kB }\end{array}$ & [63] \\
\hline & ovarian cancer cell line, OAW42-A & $12.5,25,50 \mu \mathrm{M}$ & $\begin{array}{l}\text { Reduced the mitochondrial membrane potential; increased protein } \\
\text { expression of LC3 II and beclin } 1\end{array}$ & [64] \\
\hline \multirow{3}{*}{$\begin{array}{l}\text { ER stress-mediated } \\
\text { apoptosis }\end{array}$} & A549 lung adenocarcinoma cells & $10,20,30 \mu \mathrm{M}$ & $\begin{array}{l}\text { Activated UPR signaling pathways; upregulated GRP78 and IRE1 } \alpha \\
\text { expression; induced ASK1 and JNK activation }\end{array}$ & [65] \\
\hline & $\begin{array}{l}\text { U2OS human osteosarcoma cells, A549 human } \\
\text { alveolar adenocarcinoma cells, Hela cells }\end{array}$ & $10,20,30 \mu \mathrm{M}$ & $\begin{array}{l}\text { Increased expressions of Bip and IREa; increased expressions of } \\
\text { p-ASK1, p-JNK and p-ERK; induced generation of } \mathrm{Ca}^{2+}\end{array}$ & [66] \\
\hline & HCT-116, HT-29, SW620 colon cancer cells & $10,20,30 \mu \mathrm{M}$ & $\begin{array}{l}\text { Inhibited the activity of TrxR1; induced the expression of p-eIF2a, } \\
\text { ATF4 and CHOP }\end{array}$ & {$[67]$} \\
\hline $\begin{array}{l}\text { Death receptor } \\
\text { mediated apoptosis }\end{array}$ & NALM-6 human B cell leukemia cell & $10 \mu \mathrm{M}$ & Increased the phosphorylation of FADD; activated caspase- 8 & \multirow[t]{2}{*}[68]{} \\
\hline \multirow{5}{*}{ TERT inhibition } & NALM-6 human B cell leukemia cell & $10 \mu \mathrm{M}$ & $\begin{array}{l}\text { Suppressed telomerase activity; inhibited the expression of hTERT } \\
\text { mRNA and protein }\end{array}$ & \\
\hline & MCF-7, MDA-MB-231 breast cancer cells & $10,50,80,100 \mu \mathrm{M}$ & $\begin{array}{l}\text { Inhibited the cell growth, telomerase activity and hTERT mRNA } \\
\text { expression; inhibited bindings of hTERT promoters; inhibited the } \\
\text { expression of c-Myc and Sp1 }\end{array}$ & [69] \\
\hline & A172, U87MG, T98G glioma cells & $10,20,30,40 \mu \mathrm{M}$ & $\begin{array}{c}\text { Decreases Nrf2 levels; Suppressed telomerase activity; decreased } \\
\text { expression of G6PD and TKT }\end{array}$ & {$[70]$} \\
\hline & A172, U87MG glioma cells & $30 \mu \mathrm{M}$ & Inhibited hTERT expression & [71] \\
\hline & HepG2/C3A, PLC/PRF/5 HCC cells & $5,10,50 \mu \mathrm{M}$ & $\begin{array}{l}\text { Inhibited AFP secretion and mRNA expression; decreased cell } \\
\text { migration }\end{array}$ & [72] \\
\hline
\end{tabular}


Table 2. Cont

\begin{tabular}{|c|c|c|c|c|}
\hline Type & Experimental Model & Dose/Concentration & Mechanism of Action & Ref. \\
\hline \multirow{3}{*}{$\begin{array}{l}\text { Inhibition of } \\
\text { angiogenesis }\end{array}$} & subcutaneous murine sponge model & $5,10,20 \mathrm{mg} / \mathrm{kg}$ & Reduced hemoglobin concentration and VEGF levels & [74] \\
\hline & VEGF-stimulated HUVECs & $\mathrm{IC}_{50} 5.7 \mu \mathrm{M}$ & $\begin{array}{l}\text { Inhibited VEGF-induced proliferation and migration; inhibited the } \\
\text { VEGF-induced autophosphorylation of KDR/Flk-1 }\end{array}$ & [75] \\
\hline & AGS, Caco-2, HepG2/C3A cancer cells & $10 \mu \mathrm{M}$ & Decreased VEGF secretion and mRNA levels & [76] \\
\hline \multirow{5}{*}{$\begin{array}{l}\text { Inhibition of tumor } \\
\text { metastasis }\end{array}$} & MDA-MB-231 breast cancer cells & $20 \mu \mathrm{M}$ & $\begin{array}{l}\text { Inhibited TNF } \alpha \text {-induced cells migration and invasion; reduced } \\
\text { phosphorylation of IKK and IкB } \alpha \text {; inhibited p } 65 \text { NF- } \kappa \text { B subunit }\end{array}$ & [77] \\
\hline & IMR-32, LA-N-1, SK-N-SH neuroblastoma cell & $0.1,1,10 \mu \mathrm{M}$ & Inhibited migration and invasion; suppressed MMP2 expression & [78] \\
\hline & SW-872, SW-982, TE-671 soft tissue sarcomas & $3,10,20 \mu \mathrm{g} / \mathrm{mL}$ & Inhibited the invasion potential; changed the expression of MMPs & [79] \\
\hline & $\begin{array}{l}\text { TR-LE (temperature-sensitive rat lymphatic } \\
\text { endothelial) cells }\end{array}$ & $\mathrm{IC}_{50} 1.37 \mu \mathrm{M}$ & Suppressed cell proliferation; inhibited capillary-like tube formation & [80] \\
\hline & $\begin{array}{c}\text { MDA-MB-157, MDA-MB-436, Bt-549 breast cancer } \\
\text { cells }\end{array}$ & $10,25 \mu \mathrm{M}$ & $\begin{array}{l}\text { Reduced detyrosinated tubulin; decreased microtentacle (McTN) } \\
\text { frequency; reduced tumor cell attachment }\end{array}$ & [81] \\
\hline \multirow{2}{*}{ Antidiabetic effect } & $\begin{array}{l}\alpha \text {-Amylase, } \alpha \text {-Glucosidase, fructosamine } \\
\text { formation, glycation }\end{array}$ & $\mathrm{IC}_{50} 5.88$ or $67.5 \mu \mathrm{M}$ & $\begin{array}{l}\text { Inhibited the activity of } \alpha \text {-Amylase, } \alpha \text {-Glucosidase; inhibited } \\
\text { fructosamine formation; }\end{array}$ & [82] \\
\hline & streptozotocin-induced diabetic rats & $5,10,20 \mathrm{mg} / \mathrm{kg}$ & $\begin{array}{l}\text { Reduced glucose levels and } \mathrm{HbA}_{1 c} \text {; increased insulin levels; reduced } \\
\text { cholesterol, TG, LDL; increased HDL }\end{array}$ & {$[8]$} \\
\hline
\end{tabular}


Funding: This research received no external funding.

Conflicts of Interest: The author declares no conflict of interest.

\section{Abbreviations}

Akt: protein kinase B; ALP: alkaline phosphatase; AP-1: activator protein-1; ASYN: $\alpha$-synuclein; ATF4: transcription factor 4; BAX: BCL2 Associated X; BCL-2: B-cell lymphoma 2; Bcl-xL: B-cell lymphoma-extra large; BID BH3: interacting-domain death agonist; Bip: binding immunoglobulin protein; CCL: C-C motif ligand; Cdc2: cell division cycle protein 2 homolog; Cdk: cyclin-dependent kinases; Chk2: checkpoint kinase 2; COX: cyclooxygenase; DAT: dopamine transporter; Dlx5: distal-less homeobox 5; ECM: extracellular matrix; EMT: Epithelial-messenchymal transition; ER: estrogen receptor; ERK: extracellular signal-regulated kinase; GATA-3: GATA-Binding Protein 3; GLS1: glutaminase 1; GPx: glutathione peroxidase; GSH: glutathione; GST: glutathione-S-transferase; HBeAg: hepatitis B e antigen; HBsAg: hepatitis B surface antigen; HO-1: heme oxygenase-1; hTERT: human telomerase reverse transcriptase; ICAM-1: intracellular adhesion molecule-1; IFN- $\gamma$ : Interferon gamma; IM: intestinal mucositis; iNOS: inducible nitric oxide synthase; JAK: Janus-activated kinase; JNK: c-Jun N-terminal kinases; KDR/Flk-1: kinase insert domain receptor; LPS: lipopolysaccharide; MAPK: mitogen-activated protein kinase; MCP-1: macrophage chemoattractant protein-1; McTN : microtentacles; MDC: Macrophage-Derived Chemokine; MDM2: Mouse double minute 2 homolog; MMP: matrix metalloproteinase; MMP: mitochondrial membrane potential; MPO: myeloperoxidase; mTOR: mammalian target of rapamycin; NAG: $N$-acetylglucosaminidase; NF-кB: nuclear factor-kappaB; NFATc1: nuclear factor of activated T cells, cystoplasic-1; NO: nitric oxide; Nrf2: nuclear factor erythroidrelated factor-2; Nurr1: nuclear receptor related-1; OC: osteocalcin; OSCAR: osteoclast-associated receptor; OVA: ovalbumin; PERK: pancreatic ER kinase; PI3K: phoaphatidylinositol-3-kinase; RANKL: receptor activator of nuclear factor kappa-B ligand; RANTES: regulated on activation, normal T cell expressed and secreted; Rb: retinoblastoma protein; ROR $\gamma \mathbf{t}$ : RAR-related orphan receptor $\gamma \mathrm{t}$; ROS: reactive oxygen species; Runx2: runt-related transcription factor 2; SN: substantia nigra; SNPP: Simple Network Paging Protocol; SOD: superoxide dismutase; STAT: signal transducer and activator of transcription; T-bet: T-box transcription factor; TAK1: transforming growth factor- $\beta$-activated kinase 1 ; TARC: thymus and activation regulated chemokine; TGF- $\beta 1$ : transforming growth factor; TNF- $\alpha$ : tumor necrosis factor alpha; TRAP: tartrate-resistant acid phosphatase; TrxR: thioredoxin/thioredoxin reductase; VEGF: vascular endothelial growth factor; VMAT2: vesicular monoamine transporter type 2.

\section{References}

1. Lahlou, M. The success of natural products in drug discovery. Pharmacol. Pharm. 2013, 4, 17-31. [CrossRef]

2. Wang, G.; Tang, W.; Bidigare, R.R. Terpenoids as therapeutic drugs and pharmaceutical agents. In Natural Products; Springer: Berlin, Germany, 2005; pp. 197-227.

3. De Kraker, J.-W.; Franssen, M.C.; Dalm, M.C.; de Groot, A.; Bouwmeester, H.J. Biosynthesis of germacrene A carboxylic acid in chicory roots. Demonstration of a cytochrome P450 (+)-germacrene A hydroxylase and NADP+-dependent sesquiterpenoid dehydrogenase (s) involved in sesquiterpene lactone biosynthesis. Plant Physiol. 2001, 125, 1930-1940. [CrossRef] [PubMed]

4. Yang, Z.-J.; Ge, W.-Z.; Li, Q.-Y.; Lu, Y.; Gong, J.-M.; Kuang, B.-J.; Xi, X.; Wu, H.; Zhang, Q.; Chen, Y. Syntheses and biological evaluation of costunolide, parthenolide, and their fluorinated analogues. J. Med. Chem. 2015, 58, 7007-7020. [CrossRef] [PubMed]

5. Rasul, A.; Parveen, S.; Ma, T. Costunolide: A novel anti Costunolide: A novel anti-cancer sesquiterpene lactone cancer sesquiterpene lactone cancer sesquiterpene lactone. Bangladesh J. Pharmacol. 2012, 7, 6-13. [CrossRef]

6. Rao, A.S.; Kelkar, G.; Bhattacharyya, S. Terpenoids-XXI: The structure of costunolide, a new sesquiterpene lactone from costus root oil. Tetrahedron 1960, 9, 275-283. [CrossRef]

7. Rice-Evans, C. Flavonoids and isoflavones: Absorption, metabolism, and bioactivity. Free Radic. Biol. Med. 2004, 7, 827-828. [CrossRef] [PubMed]

8. Eliza, J.; Daisy, P.; Ignacimuthu, S. Antioxidant activity of costunolide and eremanthin isolated from Costus speciosus (Koen ex. Retz) Sm. Chem. Biol. Interact. 2010, 188, 467-472. [CrossRef]

9. Wu, G.; Fang, Y.-Z.; Yang, S.; Lupton, J.R.; Turner, N.D. Glutathione metabolism and its implications for health. J. Nutr. 2004, 134, 489-492. [CrossRef]

10. Rajalakshmi, M.; Anita, R. In vitro and in silico evaluation of antioxidant activity of a sesquiterpene lactone, costunolide, isolated from costus specious rhizome on MCF-7 and MDA-MB-231 human breast cancer cell lines. World J. Pharm. Pharm. Sci. 2014, 3, 1334-1347.

11. Chen, Y.; Zheng, H.; Zhang, J.; Wang, L.; Jin, Z.; Gao, W. Intestinal mucositis repaired activity of costunolide and dehydrocostus in 5-fluorouracil-induced mice model. RSC. Adv. 2016, 6, 5249-5258. [CrossRef] 
12. Cheong, C.-U.; Yeh, C.-S.; Hsieh, Y.-W.; Lee, Y.-R.; Lin, M.-Y.; Chen, C.-Y.; Lee, C.-H. Protective effects of Costunolide against hydrogen peroxide-induced injury in PC12 cells. Molecules 2016, 21, 898. [CrossRef] [PubMed]

13. Kassuya, C.A.L.; Cremoneze, A.; Barros, L.F.L.; Simas, A.S.; da Rocha Lapa, F.; Mello-Silva, R.; Stefanello, M.É.A.; Zampronio, A.R. Antipyretic and anti-inflammatory properties of the ethanolic extract, dichloromethane fraction and costunolide from Magnolia ovata (Magnoliaceae). J. Ethnopharmacol. 2009, 124, 369-376. [CrossRef] [PubMed]

14. Koo, T.H.; Lee, J.-H.; Park, Y.J.; Hong, Y.-S.; Kim, H.S.; Kim, K.-W.; Lee, J.J. A sesquiterpene lactone, costunolide, from Magnolia grandiflora inhibits NF-кB by targeting IкB phosphorylation. Planta Med. 2001, 67, 103-107. [CrossRef] [PubMed]

15. Scarponi, C.; Butturini, E.; Sestito, R.; Madonna, S.; Cavani, A.; Mariotto, S.; Albanesi, C. Inhibition of inflammatory and proliferative responses of human keratinocytes exposed to the sesquiterpene lactones dehydrocostuslactone and costunolide. PLoS ONE 2014, 9, e107904. [CrossRef] [PubMed]

16. Butturini, E.; Cavalieri, E.; de Prati, A.C.; Darra, E.; Rigo, A.; Shoji, K.; Murayama, N.; Yamazaki, H.; Watanabe, Y.; Suzuki, H. Two naturally occurring terpenes, dehydrocostuslactone and costunolide, decrease intracellular GSH content and inhibit STAT3 activation. PLoS ONE 2011, 6, e20174. [CrossRef] [PubMed]

17. Zheng, H.; Chen, Y.; Zhang, J.; Wang, L.; Jin, Z.; Huang, H.; Man, S.; Gao, W. Evaluation of protective effects of costunolide and dehydrocostuslactone on ethanol-induced gastric ulcer in mice based on multi-pathway regulation. Chem. Biol. Interact. 2016, 250, 68-77. [CrossRef] [PubMed]

18. Kang, J.S.; Yoon, Y.D.; Lee, K.H.; Park, S.-K.; Kim, H.M. Costunolide inhibits interleukin-1 $\beta$ expression by down-regulation of AP-1 and MAPK activity in LPS-stimulated RAW 264.7 cells. Biochem. Biophys. Res. Commun. 2004, 313, 171-177. [CrossRef] [PubMed]

19. Butturini, E.; Di Paola, R.; Suzuki, H.; Paterniti, I.; Ahmad, A.; Mariotto, S.; Cuzzocrea, S. Costunolide and Dehydrocostuslactone, two natural sesquiterpene lactones, ameliorate the inflammatory process associated to experimental pleurisy in mice. Eur. J. Pharmacol. 2014, 730, 107-115. [CrossRef] [PubMed]

20. Prawan, A.; Kundu, J.K.; Surh, Y.J. Molecular basis of heme oxygenase-1 induction: Implications for chemoprevention and chemoprotection. Antioxid. Redox Signal. 2005, 7, 1688-1703. [CrossRef]

21. Pae, H.-O.; Jeong, G.-S.; Kim, H.-S.; Woo, W.; Rhew, H.; Kim, H.; Sohn, D.; Kim, Y.-C.; Chung, H.-T. Costunolide inhibits production of tumor necrosis factor- $\alpha$ and interleukin- 6 by inducing heme oxygenase- 1 in RAW264. 7 macrophages. Inflamm. Res. 2007, 56, 520-526. [CrossRef]

22. Rahimi, K.; Ahmadi, A.; Hassanzadeh, K.; Soleimani, Z.; Sathyapalan, T.; Mohammadi, A.; Sahebkar, A. Targeting the balance of $\mathrm{T}$ helper cell responses by curcumin in inflammatory and autoimmune states. Autoimmun. Rev. 2019. [CrossRef] [PubMed]

23. Park, E.; Song, J.H.; Kim, M.S.; Park, S.-H.; Kim, T.S. Costunolide, a sesquiterpene lactone, inhibits the differentiation of pro-inflammatory $\mathrm{CD} 4+\mathrm{T}$ cells through the modulation of mitogen-activated protein kinases. Int. Immunopharmacol. 2016, 40, 508-516. [CrossRef] [PubMed]

24. Kim, J.E.; Kim, J.S.; Cho, D.H.; Park, H.J. Molecular Mechanisms of Cutaneous Inflammatory Disorder: Atopic Dermatitis. Int. J. Mol. Sci. 2016, 17, 1234. [CrossRef] [PubMed]

25. Seo, C.S.; Lim, H.S.; Jeong, S.J.; Shin, H.K. Anti-allergic effects of sesquiterpene lactones from the root of Aucklandia lappa Decne. Mol. Med. Rep. 2015, 12, 7789-7795. [CrossRef] [PubMed]

26. Lee, B.-K.; Park, S.-J.; Nam, S.-Y.; Kang, S.; Hwang, J.; Lee, S.-J.; Im, D.-S. Anti-allergic effects of sesquiterpene lactones from Saussurea costus (Falc.) Lipsch. determined using in vivo and in vitro experiments. J. Ethnopharmacol. 2018, 213, 256-261. [CrossRef] [PubMed]

27. Kim, T.J.; Nam, K.W.; Kim, B.; Lee, S.J.; Oh, K.B.; Kim, K.H.; Mar, W.; Shin, J. Inhibitory Effects of Costunolide Isolated from Laurus nobilis on IgE-induced Degranulation of Mast Cell-like RBL-2H3 Cells and the Growth of Y16 pro-B Cells. Phytother. Res. 2011, 25, 1392-1397. [CrossRef]

28. Khosla, S. Increasing options for the treatment of osteoporosis. N. Engl. J. Med. 2009, 361, 818-820. [CrossRef]

29. Lee, Y.S.; Choi, E.M. Costunolide stimulates the function of osteoblastic MC3T3-E1 cells. Int. Immunopharmacol. 2011, 11, 712-718. [CrossRef]

30. Jeon, W.-J.; Kim, K.-M.; Kim, E.-J.; Jang, W.-G. Costunolide increases osteoblast differentiation via ATF4-dependent HO-1 expression in C3H10T1/2 cells. Life Sci. 2017, 178, 94-99. [CrossRef] 
31. Cheon, Y.H.; Song, M.J.; Kim, J.Y.; Kwak, S.C.; Park, J.H.; Lee, C.H.; Kim, J.J.; Kim, J.Y.; Choi, M.K.; Oh, J. Costunolide Inhibits Osteoclast Differentiation by Suppressing c-Fos Transcriptional Activity. Phytother. Res. 2014, 28, 586-592. [CrossRef]

32. Hermanson, E.; Joseph, B.; Castro, D.; Lindqvist, E.; Aarnisalo, P.; Wallen, A.; Benoit, G.; Hengerer, B.; Olson, L.; Perlmann, T. Nurr1 regulates dopamine synthesis and storage in MN9D dopamine cells. Exp. Cell Res. 2003, 288, 324-334. [CrossRef]

33. Ham, A.; Lee, S.-J.; Shin, J.; Kim, K.-H.; Mar, W. Regulatory effects of costunolide on dopamine metabolism-associated genes inhibit dopamine-induced apoptosis in human dopaminergic SH-SY5Y cells. Neurosci. Lett. 2012, 507, 101-105. [CrossRef] [PubMed]

34. Rayan, N.; Baby, N.; Pitchai, D.; Indraswari, F.; Ling, E.; Lu, J.; Dheen, T. Costunolide inhibits proinflammatory cytokines and iNOS in activated murine BV2 microglia. Front. Biosci. (Elite Ed.) 2011, 3, 1079-1091. [CrossRef] [PubMed]

35. Luna-Herrera, J.; Costa, M.; Gonzalez, H.; Rodrigues, A.; Castilho, P. Synergistic antimycobacterial activities of sesquiterpene lactones from Laurus spp. J. Antimicrob. Chemother. 2007, 59, 548-552. [CrossRef] [PubMed]

36. Fischer, N.H.; Lu, T.; Cantrell, C.L.; Castañeda-Acosta, J.; Quijano, L.; Franzblau, S.G. Antimycobacterial evaluation of germacranolides in honour of professor GH Neil Towers 75th birthday. Phytochemistry 1998, 49, 559-564. [CrossRef]

37. Alaagib, R.M.O.; Ayoub, S.M.H. On the chemical composition and antibacterial activity of Saussurea lappa (Asteraceae). Pharma Innov. 2015, 4 Pt C, 73-76.

38. Park, J.-B.; Lee, C.-K.; Park, H.J. Anti-Helicobacter pylori effect of costunolide isolated from the stem bark ofMagnolia sieboldii. Arch. Pharmacal Res. 1997, 20, 275. [CrossRef] [PubMed]

39. Duraipandiyan, V.; Al-Harbi, N.A.; Ignacimuthu, S.; Muthukumar, C. Antimicrobial activity of sesquiterpene lactones isolated from traditional medicinal plant, Costus speciosus (Koen ex. Retz.) Sm. BMC Complement. Altern. Med. 2012, 12, 13. [CrossRef]

40. Wedge, D.; Galindo, J.; Macias, F. Fungicidal activity of natural and synthetic sesquiterpene lactone analogs. Phytochemistry 2000, 53, 747-757. [CrossRef]

41. Barrero, A.F.; Oltra, J.E.; Álvarez, M.R.; Raslan, D.S.; Saúde, D.A.; Akssira, M. New sources and antifungal activity of sesquiterpene lactones. Fitoterapia 2000, 71, 60-64. [CrossRef]

42. Chen, H.-C.; Chou, C.-K.; Lee, S.-D.; Wang, J.-C.; Yeh, S.-F. Active compounds from Saussurea lappa Clarks that suppress hepatitis B virus surface antigen gene expression in human hepatoma cells. Antivir. Res. 1995, 27, 99-109. [CrossRef]

43. Chen, Z.; Zhang, D.; Li, M.; Wang, B. Costunolide ameliorates lipoteichoic acid-induced acute lung injury via attenuating MAPK signaling pathway. Int. Immunopharmacol. 2018, 61, 283-289. [CrossRef] [PubMed]

44. Choi, B.Y. Hair-Growth Potential of Ginseng and Its Major Metabolites: A Review on Its Molecular Mechanisms. Int. J. Mol. Sci 2018, 19, 2703. [CrossRef] [PubMed]

45. Madaan, A.; Verma, R.; Singh, A.T.; Jaggi, M. Review of Hair Follicle Dermal Papilla cells as in vitro screening model for hair growth. Int. J. Cosmet. Sci. 2018, 40, 429-450. [CrossRef] [PubMed]

46. Kim, Y.E.; Choi, H.C.; Nam, G.; Choi, B.Y. Costunolide promotes the proliferation of human hair follicle dermal papilla cells and induces hair growth in C57 BL/6 mice. J. Cosmet. Dermatol. 2018, 18, 414-421. [CrossRef] [PubMed]

47. Bocca, C.; Gabriel, L.; Bozzo, F.; Miglietta, A. A sesquiterpene lactone, costunolide, interacts with microtubule protein and inhibits the growth of MCF-7 cells. Chem. Biol. Interact. 2004, 147, 79-86. [CrossRef] [PubMed]

48. Cai, H.; He, X.; Yang, C. Costunolide promotes imatinib-induced apoptosis in chronic myeloid leukemia cells via the Bcr/Abl-Stat5 pathway. Phytother. Res. 2018, 32, 1764-1769. [CrossRef] [PubMed]

49. Dong, G.Z.; Shim, A.R.; Hyeon, J.S.; Lee, H.J.; Ryu, J.H. Inhibition of Wnt/ß-Catenin Pathway by Dehydrocostus Lactone and Costunolide in Colon Cancer Cells. Phytother. Res. 2015, 29, 680-686. [CrossRef] [PubMed]

50. Hsu, J.-L.; Pan, S.-L.; Ho, Y.-F.; Hwang, T.-L.; Kung, F.-L.; Guh, J.-H. Costunolide induces apoptosis through nuclear calcium2+ overload and DNA damage response in human prostate cancer. J. Urol. 2011, 185, 1967-1974. [CrossRef] [PubMed]

51. Liu, C.-Y.; Chang, H.-S.; Chen, I.-S.; Chen, C.-J.; Hsu, M.-L.; Fu, S.-L.; Chen, Y.-J. Costunolide causes mitotic arrest and enhances radiosensitivity in human hepatocellular carcinoma cells. Radiat. Oncol. 2011, 6, 56. [CrossRef] [PubMed] 
52. Hu, M.; Liu, L.; Yao, W. Activation of p53 by costunolide blocks glutaminolysis and inhibits proliferation in human colorectal cancer cells. Gene 2018, 678, 261-269. [CrossRef] [PubMed]

53. Hua, P.; Zhang, G.; Zhang, Y.; Sun, M.; Cui, R.; Li, X.; Li, B.; Zhang, X. Costunolide induces G1/S phase arrest and activates mitochondrial-mediated apoptotic pathways in SK-MES 1 human lung squamous carcinoma cells. Oncol. Lett. 2016, 11, 2780-2786. [CrossRef] [PubMed]

54. Rasul, A.; Yu, B.; Yang, L.-F.; Arshad, M.; Khan, M.; Ma, T.; Yang, H. Costunolide, a sesquiterpene lactone induces G2/M phase arrest and mitochondria-mediated apoptosis in human gastric adenocarcinoma SGC-7901 cells. J. Med. Plants Res. 2012, 6, 1191-1200.

55. Peng, Z.; Wang, Y.; Fan, J.; Lin, X.; Liu, C.; Xu, Y.; Ji, W.; Yan, C.; Su, C. Costunolide and dehydrocostuslactone combination treatment inhibit breast cancer by inducing cell cycle arrest and apoptosis through c-Myc/p53 and AKT/14-3-3 pathway. Sci. Rep. 2017, 7, 41254. [CrossRef] [PubMed]

56. Choi, Y.K.; Seo, H.S.; Choi, H.S.; Choi, H.S.; Kim, S.R.; Shin, Y.C.; Ko, S.-G. Induction of Fas-mediated extrinsic apoptosis, p21WAF1-related G2/M cell cycle arrest and ROS generation by costunolide in estrogen receptor-negative breast cancer cells, MDA-MB-231. Mol. Cell. Biochem. 2012, 363, 119-128. [CrossRef] [PubMed]

57. Roy, A.; Manikkam, R. Cytotoxic Impact of Costunolide Isolated from Costus speciosus on Breast Cancer via Differential Regulation of Cell Cycle-An In-vitro and In-silico Approach. Phytother. Res. 2015, 29, 1532-1539. [CrossRef] [PubMed]

58. Cai, H.; Li, L.; Jiang, J.; Zhao, C.; Yang, C. Costunolide enhances sensitivity of K562/ADR chronic myeloid leukemia cells to doxorubicin through PI3K/Akt pathway. Phytother. Res. 2019. [CrossRef] [PubMed]

59. Hua, P.; Sun, M.; Zhang, G.; Zhang, Y.; Song, G.; Liu, Z.; Li, X.; Zhang, X.; Li, B. Costunolide Induces Apoptosis through Generation of ROS and Activation of P53 in Human Esophageal Cancer Eca-109 Cells. J. Biochem. Mol. Toxicol. 2016, 30, 462-469. [CrossRef]

60. Chen, J.; Chen, B.; Zou, Z.; Li, W.; Zhang, Y.; Xie, J.; Liu, C. Costunolide enhances doxorubicin-induced apoptosis in prostate cancer cells via activated mitogen-activated protein kinases and generation of reactive oxygen species. Oncotarget 2017, 8, 107701-107705. [CrossRef]

61. Rasul, A.; Bao, R.; Malhi, M.; Zhao, B.; Tsuji, I.; Li, J.; Li, X. Induction of apoptosis by costunolide in bladder cancer cells is mediated through ROS generation and mitochondrial dysfunction. Molecules 2013, 18, 1418-1433. [CrossRef]

62. Choi, J.-H.; Lee, K.-T. Costunolide-induced apoptosis in human leukemia cells: Involvement of c-jun N-terminal kinase activation. Biol. Pharm. Bull. 2009, 32, 1803-1808. [CrossRef] [PubMed]

63. Yang, Y.-I.; Kim, J.-H.; Lee, K.-T.; Choi, J.-H. Costunolide induces apoptosis in platinum-resistant human ovarian cancer cells by generating reactive oxygen species. Gynecol. Oncol. 2011, 123, 588-596. [CrossRef] [PubMed]

64. Kim, J.-H.; Yang, Y.-I.; Lee, K.-T.; Park, H.-J.; Choi, J.-H. Costunolide induces apoptosis in human endometriotic cells through inhibition of the prosurvival Akt and nuclear factor kappa B signaling pathway. Biol. Pharm. Bull. 2011, 34, 580-585. [CrossRef] [PubMed]

65. Fang, Y.; Li, J.; Wu, Y.; Gui, J.; Shen, Y. Costunolide Inhibits the Growth of OAW42-A Multidrug-Resistant Human Ovarian Cancer Cells by Activating Apoptotic and Autophagic Pathways, Production of Reactive Oxygen Species (ROS), Cleaved Caspase-3 and Cleaved Caspase-9. Med. Sci. Monit. 2019, 25, 3231-3237. [CrossRef] [PubMed]

66. Wang, Z.; Zhao, X.; Gong, X. Costunolide induces lung adenocarcinoma cell line A549 cells apoptosis through ROS (reactive oxygen species)—Mediated endoplasmic reticulum stress. Cell Biol. Int. 2016, 40, 289-297. [CrossRef] [PubMed]

67. Zhang, C.; Lu, T.; Wang, G.-D.; Ma, C.; Zhou, Y.-F. Costunolide, an active sesquiterpene lactone, induced apoptosis via ROS-mediated ER stress and JNK pathway in human U2OS cells. Biomed. Pharmacother. 2016, 80, 253-259. [CrossRef] [PubMed]

68. Zhuge, W.; Chen, R.; Vladimir, K.; Dong, X.; Zia, K.; Sun, X.; Dai, X.; Bao, M.; Shen, X.; Liang, G. Costunolide specifically binds and inhibits thioredoxin reductase 1 to induce apoptosis in colon cancer. Cancer Lett. 2018, 412, 46-58. [CrossRef]

69. Kanno, S.-I.; Kitajima, Y.; Kakuta, M.; Osanai, Y.; Kurauchi, K.; Ujibe, M.; Ishikawa, M. Costunolide-induced apoptosis is caused by receptor-mediated pathway and inhibition of telomerase activity in NALM-6 cells. Biol. Pharm. Bull. 2008, 31, 1024-1028. [CrossRef] 
70. Choi, S.-H.; Im, E.; Kang, H.K.; Lee, J.-H.; Kwak, H.-S.; Bae, Y.-T.; Park, H.-J.; Kim, N.D. Inhibitory effects of costunolide on the telomerase activity in human breast carcinoma cells. Cancer Lett. 2005, 227, 153-162. [CrossRef]

71. Ahmad, F.; Dixit, D.; Sharma, V.; Kumar, A.; Joshi, S.; Sarkar, C.; Sen, E. Nrf2-driven TERT regulates pentose phosphate pathway in glioblastoma. Cell Death Dis. 2017, 7, e2213. [CrossRef]

72. Tahtouh, R.; Azzi, A.-S.; Alaaeddine, N.; Chamat, S.; Bouharoun-Tayoun, H.; Wardi, L.; Raad, I.; Sarkis, R.; Antoun, N.A.; Hilal, G. Telomerase inhibition decreases alpha-fetoprotein expression and secretion by hepatocellular carcinoma cell lines: In vitro and in vivo study. PLoS ONE 2015, 10, e0119512. [CrossRef] [PubMed]

73. Nishida, N.; Yano, H.; Nishida, T.; Kamura, T.; Kojiro, M. Angiogenesis in cancer. Vasc. Health Risk Manag. 2006, 2, 213-219. [CrossRef]

74. Saraswati, S.; Alhaider, A.A.; Abdelgadir, A.M. Costunolide suppresses an inflammatory angiogenic response in a subcutaneous murine sponge model. Apmis 2018, 126, 257-266. [CrossRef] [PubMed]

75. Jeong, S.-J.; Itokawa, T.; Shibuya, M.; Kuwano, M.; Ono, M.; Higuchi, R.; Miyamoto, T. Costunolide, a sesquiterpene lactone from Saussurea lappa, inhibits the VEGFR KDR/Flk-1 signaling pathway. Cancer Lett. 2002, 187, 129-133. [CrossRef]

76. Mahfouz, N.; Tahtouh, R.; Alaaeddine, N.; El Hajj, J.; Sarkis, R.; Hachem, R.; Raad, I.; Hilal, G. Gastrointestinal cancer cells treatment with bevacizumab activates a VEGF autoregulatory mechanism involving telomerase catalytic subunit hTERT via PI3K-AKT, HIF-1 $\alpha$ and VEGF receptors. PLoS ONE 2017, 12, e0179202. [CrossRef] [PubMed]

77. Choi, Y.K.; Cho, S.-G.; Woo, S.-M.; Yun, Y.J.; Jo, J.; Kim, W.; Shin, Y.C.; Ko, S.-G. Saussurea lappa Clarke-derived costunolide prevents TNF $\alpha$-induced breast cancer cell migration and invasion by inhibiting NF- $\mathrm{kB}$ activity. Evid. Based Complement. Altern. Med. 2013, 2013, 936257. [CrossRef] [PubMed]

78. Tabata, K.; Nishimura, Y.; Takeda, T.; Kurita, M.; Uchiyama, T.; Suzuki, T. Sesquiterpene lactones derived from Saussurea lappa induce apoptosis and inhibit invasion and migration in neuroblastoma cells. J. Pharmacol. Sci. 2015, 127, 397-403. [CrossRef]

79. Lohberger, B.; Rinner, B.; Stuendl, N.; Kaltenegger, H.; Steinecker-Frohnwieser, B.; Bernhart, E.; Rad, E.B.; Weinberg, A.M.; Leithner, A.; Bauer, R. Sesquiterpene lactones downregulate G2/M cell cycle regulator proteins and affect the invasive potential of human soft tissue sarcoma cells. PLoS ONE 2013, 8, e66300. [CrossRef]

80. Jeong, D.; Watari, K.; Shirouzu, T.; Ono, M.; Koizumi, K.; Saiki, I.; Kim, Y.-C.; Tanaka, C.; Higuchi, R.; Miyamoto, T. Studies on lymphangiogenesis inhibitors from Korean and Japanese crude drugs. Biol. Pharm. Bull. 2013, 36, 152-157. [CrossRef]

81. Whipple, R.A.; Vitolo, M.I.; Boggs, A.E.; Charpentier, M.S.; Thompson, K.; Martin, S.S. Parthenolide and costunolide reduce microtentacles and tumor cell attachment by selectively targeting detyrosinated tubulin independent from NF-кB inhibition. Breast Cancer Res. 2013, 15, R83. [CrossRef]

82. Perera, H.K.; Premadasa, W.K.; Poongunran, J. alpha-glucosidase and glycation inhibitory effects of costus speciosus leaves. BMC Complement. Altern Med. 2016, 16, 2.

83. Eliza, J.; Daisy, P.; Ignacimuthu, S.; Duraipandiyan, V. Normo-glycemic and hypolipidemic effect of costunolide isolated from Costus speciosus (Koen ex. Retz.) Sm. in streptozotocin-induced diabetic rats. Chem. Biol. Interact. 2009, 179, 329-334. [CrossRef] [PubMed]

84. Hu, F.; Feng, S.; Wu, Y.; Bi, Y.; Wang, C.; Li, W. Quantitative analysis of costunolide and dehydrocostuslactone in rat plasma by ultraperformance liquid chromatography-electrospray ionization-mass spectrometry. Biomed. Chromatogr. 2011, 25, 547-554. [CrossRef] [PubMed]

85. Zhang, J.; Hu, X.; Gao, W.; Qu, Z.; Guo, H.; Liu, Z.; Liu, C. Pharmacokinetic study on costunolide and dehydrocostuslactone after oral administration of traditional medicine Aucklandia lappa Decne. by LC/MS/MS. J. Ethnopharmacol. 2014, 151, 191-197. [CrossRef] [PubMed]

86. Dong, S.; Ma, L.-Y.; Liu, Y.-T.; Yu, M.; Jia, H.-M.; Zhang, H.-W.; Yu, C.-Y.; Zou, Z.-M. Pharmacokinetics of costunolide and dehydrocostuslactone after oral administration of Radix aucklandiae extract in normal and gastric ulcer rats. J. Asian Nat. Prod. Res. 2018, 11, 1055-1063. [CrossRef] [PubMed]

87. Peng, Z.; Wang, Y.; Gu, X.; Guo, X.; Yan, C. Study on the pharmacokinetics and metabolism of costunolide and dehydrocostus lactone in rats by HPLC-UV and UPLC-Q-TOF/MS. Biomed. Chromatogr. 2014, 28, 1325-1334. [CrossRef] [PubMed] 
88. Singireesu, S.; Misra, S.; Mondal, S.K.; Yerramsetty, S.; Sahu, N.; Katragadda, S.B. Costunolide induces micronuclei formation, chromosomal aberrations, cytostasis, and mitochondrial-mediated apoptosis in Chinese hamster ovary cells. Cell Biol. Toxicol. 2018, 34, 125-142. [CrossRef]

89. Muschietti, L.V.; Ulloa, J.L. Natural Sesquiterpene Lactones as Potential Trypanocidal Therapeutic Agents: A Review. Nat. Prod. Commun. 2016, 11, 1569-1578. [CrossRef]

(C) 2019 by the authors. Licensee MDPI, Basel, Switzerland. This article is an open access article distributed under the terms and conditions of the Creative Commons Attribution (CC BY) license (http://creativecommons.org/licenses/by/4.0/). 